\title{
READINESS AND STAKEHOLDERS INFLUENCE FOR HALAL LOGISTICS PRACTICES IMPLEMENTATION TOWARDS SUPPLY CHAIN PERFORMANCE
}

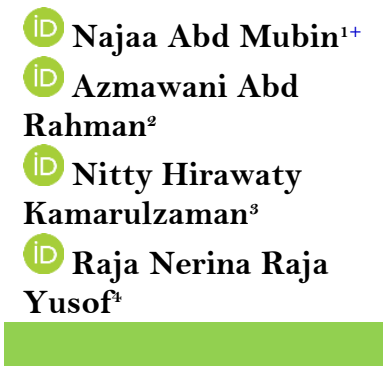

\section{Article History}

Received: 25 October 2021 Revised: 2 December 2021 Accepted: 16 December 2021 Published: 29 December 2021

\section{Keywords}

Logistics

Halal logistics

Logistics practices

Stakeholders

Stakeholders influence

Halal manufacturers

Supply chain performance.

\author{
${ }^{1,2, t}$ School of Business $\mathfrak{E}^{\circ}$ Economics, Universiti Putra Malaysia, Serdang \\ Selangor, Malaysia. \\ 'Email:najaa.amubin@gmail.com Tel: +6016-2629692 \\ 'Email:azar@upm.edu.mv Tel: +603-97697687 \\ ${ }^{4}$ Email:nerina@upm.edu.my \\ ${ }^{3}$ Faculty of Agriculture, Universiti Putra Malaysia, Serdang Selangor, \\ Malaysia. \\ ${ }^{s}$ Email:nitty@upm.edu.my Tel: +603-96794907
}

\begin{abstract}
Halal industry is expanding worldwide, and it requires strong supply chain management to enhance halal business efficiency and preserve credibility through halal logistics process. However, studies on halal logistics remain limited and isolated. Thus, this study aimed to understand the impact of stakeholders on halal logistics practices among Malaysian halal-certified manufacturers. The primary objectives of this study are to examine the underlying dimensions of halal logistics practices, investigate the level of halal logistics practices, investigate the extent of stakeholders' influence on halal logistics practices, and explore the relationship of halal logistics practices towards supply chain performance. Based on the data collected through a questionnaires survey from 270 managers from halal-certified manufacturers, SPSS and SmartPLS were used to test the hypotheses. The findings of the study indicated that operational dimensions are the most practiced dimensions of halal logistics amongst firms. Meanwhile, competitors, government, NGOs, community media and society, and customers significantly influence the adoption of halal logistics practices. Importantly, halal logistics practices are positively related to supply chain performance. This study has extended the feasibility of stakeholder theory in the sense of halal logistics to the scope and comprehensiveness of stakeholders. The outcome of this study provides important implications to both academics and practitioners, particularly in the halal industry.
\end{abstract}

Contribution/ Originality: This study contributes to the existing literature that stakeholders impact halal logistics practices. The best way to maintain halal integrity in the pipeline is to well-defined halal handling with appropriate norms and regulations. Significant findings on the stakeholder influences on halal logistics practices implementations are unique in the halal field.

\section{INTRODUCTION}

Malaysia is committed to reviving its halal industry affected by the COVID-19 pandemic by making it an essential agenda in the National Recovery Plan. The Prime Minister of Malaysia, Datuk Seri Ismail Sabri Yaakob, explains that the halal industry is a catalyst for economic resilience after COVID-19 for Malaysia and the Muslim country (Halid, 2012). Furthermore, DinarStandard (2020) highlighted that the global halal industry market size was projected to be worth US $\$ 5$ trillion in 2030 from its current market worth of US $\$ 3.1$ trillion, including the 
non-Muslims consumers moving to and consuming halal products. Malaysia itself is forecast to contribute USD113.2 billion of the halal market size in 2030. Halal is an Arabic word that means permissible or legal under Islamic law.

Even though halal is a lucrative business with strong support from various countries towards the halal economy, the halal industry is still facing challenges in its global outreach. The multiple authorized halal certification bodies coming from numerous countries signify the unstandardized halal certificate worldwide, which may cause issues and difficulties to the supply chain activities. Additionally, different halal certification bodies have produced other logos for their halal goods. Thus, cross-border activities require extensive logistics functions to avoid halal products becoming contaminated with the raw material during the change of custody. As such, the adoption of halal logistics is pertinent to ensure the development of the halal industry (Abd Rahman, Abd Mubin, Yusof, \& Kamarulzaman, 2021).

In the Halal Industry Malaysia Plan 2030, Malaysia aims to achieve socio-economic development by leading the global halal industry. It is pertinent for halal product manufacturers in Malaysia to possess operational excellence through efficient logistics functions to remain competitive and productive. Logistics plays a vital role in today's business in providing a competitive advantage to the companies through reducing cost and time. A comprehensive system is needed for halal-certified manufacturers to establish halal products with shariah-compliant and sustainable halal assurance. It includes shariah compliance to the logistics activities. Shariah compliance means it is permissible by Islamic law.

Despite the importance of logistics function to support halal assurance, there is a limited understanding of how far halal-certified manufacturers are ready towards halal logistics practices. It is critical to measure their readiness using the dimension consistent with the Malaysian Standard (MS) 2400:2019 Halal Supply Chain Management System. There has been a very slow adoption of the MS 2400:2019 Halal Supply Chain Management System among halal-certified halal manufacturers in Malaysia. One of the critical readiness and implementation factors is the role of stakeholders.

Previous researchers have investigated the broader scope of stakeholder contributions to the long-term value of the firm and the influence of stakeholders towards the firms' responses on innovation implementation (Meixell \& Luoma, 2015). However, the previous research on stakeholder influences was in conventional logistics such as environmental practices (Sarkis, Gonzalez-Torre, \& Adenso-Diaz, 2010) and sustainability (Sharma \& Henriques, 2005). Due to the unique environment of the halal industry and the complexity of the supply chain resulting from the inconsistency of the halal certification, there is a specific need to study stakeholder influences towards halal logistics practices.

Firms should also be driven to maintain internal quality levels actively and proactively manage their supply network partners (Bernon, Bastl, Zhang, \& Johnson, 2018). Furthermore, the relationship between stakeholders and firms has been identified as one of the most significant factors affecting the network structure (Macchion, Danese, \& Vinelli, 2015). This paper, therefore, focusses on three key objectives, which are to examine the underlying dimensions of halal logistics practices, to investigate the level of readiness towards halal logistics practices, and to see the extend of stakeholders' influence and reaction on halal logistics practices of halal-certified manufacturers of food, pharmaceutical, and cosmetics product.

\section{UNDERSTANDING HALAL LOGISTICS}

The concept of Halal starts from the time of production and continues until the time of consumption. It indicates that managing halal requires a supply chain management strategy from the origin of the material until the final consumption. Halal logistics includes planning, implementing, and controlling the change of custody for halal goods, including distribution, transportation, storage and warehousing, material and inventory management, and receiving must be Shariah compliance to meet the total supply chain objective as a whole. Even though 
conventional logistics and halal logistics have a similar definition, halal logistics forced logistics players to dedicate the facilities and equipment specification for halal-certified goods.

Logistics functions are linked to manufacturing activities, including transportation, warehousing, packaging, and retailing. However, most businesses are still hesitant in adopting halal logistics in their business operation (Ngah, Zainuddin, \& Thurasamy, 2015) due to high capital expenditure and are claimed as not cost-effective (Ab Talib, Rubin, \& Zhengyi, 2013). Thus, an in-depth study on halal logistics practices is required since logistics have been reported to improve supply chain performance. The Malaysian Standard MS2400:2019 Halal Supply Chain Management System is the primary reference used to develop the logistics framework in this research.

For halal-certified manufacturers, a comprehensive system must establish the production of halal products that are shariah compliant. Establishing a credible approach is crucial to maintaining halal product integrity (Abd Rahman \& Abdul, 2017). In collaboration with the Department of Standard Malaysia, the Department of Islamic Development Malaysia (JAKIM) has developed national standards to suit the requirement and needs of the halal industry in Malaysia. The Malaysian standard MS2400:2019 Halal Supply Chain Management System is an improved version from the MS2400:2010 Halalan Toyyiban Assurance Pipeline. It covers transportation, warehousing, and retail. Since the measurement of halal logistics remains limited and isolated, this study proposed a holistic view of halal logistics practices regarding the stakeholders' influence. This study suggests four new dimensions of halal logistics practices: management responsibility, risk management analysis, risk management process, and operation.

\section{THEORETICAL FRAMEWORK AND HYPOTHESES DEVELOPMENT}

In the early 21 st century, stakeholders have increased their influence on firm activities in which all stakeholders will carry weight in the firm decisions. The stakeholder can be defined as individuals or groups that may influence or be influenced by the scope of company objectives (Backer, 2007). Thus, a person, an informal group, a company, or an institution may be stakeholders. They have the power over the firm's behavior and performance by affecting the firms' operation. As the business firm focused on maximizing profit, stakeholders demanded that businesses uphold a higher standard and influence their decision-making. Stakeholders were insisting more dynamic, stimulating, and rewarding work environment to create a better work environment.

The awareness between all industries players has not been widely discussed in the previous studies of halal logistics industries (Jaafar, Faisol, Abdul Rahman, \& Muhammad, 2017; Samsi, Tasnim, \& Ibrahim, 2011; Yunos, Mahmood, \& Abd Mansor, 2014). Even though much research and development activities have been carried out to develop halal products, the focus has been on halal ingredients in the halal food and pharmaceutical products and lack of study in halal logistics and supply chain. Furthermore, the awareness and comprehension of the concepts of halal logistics within industry players or stakeholders are minimal.

A literature review indicates that different studies have used different definitions of stakeholders and have considered various stakeholders in their research. Samsi et al. (2011) have considered government, customers, trade associations, suppliers, NGOs, and employees stakeholders within the halal analysis. Meanwhile, Yunos et al. (2014) and Haleem and Khan (2017) have justified stakeholders are government or regulators, customers, and the public in their studies. Based on the literature review and feedback from preliminary fieldwork, this study has considered customers, suppliers, competitors, government, NGOs, community media, and society as the relevant stakeholders in the halal logistics industry.

Various previous research findings have provided evidence that implementing systems depends on external influence, especially from stakeholders such as project management (Zidane, Johansen, Ekambaram, \& Hald, 2015) and in the mental healthcare area (Bierbooms, Van Oers, Rijkers, \& Bongers, 2016). The previous finding highlighted those critical failure factors of implementation halal logistics practices are related to the stakeholders, such as lack of collaboration between logistics practitioners and government (Haleem \& Khan, 2017), lack of 
demand on halal logistics (Hima, Rahim, Mohd, \& Zainuddin, 2016) and no authority enforcement on implementation of halal logistics (Ab Talib \& Hamid, 2004; Abd Rahman et al., 2021). Besides, publications on stakeholders' influences are limited in number and depth. The study from Samsi et al. (2011) offered almost similar findings of stakeholders; however, the publication only focused on the conceptual result. Thus, this study focused on empirical impact, which has been tested in halal-certified manufacturers in Malaysia.

Stakeholders are the most influential people to the development standard (Balzarova \& Castka, 2012) especially when the stakeholders are more knowledgeable about the new practices' implementation. These stakeholders have the power to become influential to the firms. Stakeholders such as consumers, employees, government, and activists demand that businesses uphold a higher standard. It creates pressure towards firms to provide more benefits in terms of economics and society. A firm's success depends on how well it manages the relationship with its stakeholders (Freeman \& Phillips, 2002). The involvement of stakeholders in the business process will decide the competitiveness of the firm's ongoing business. With the support from stakeholders, changing products and processes enhance the firms' performance (Russo \& Perrini, 2010). Besides that, business is about how the stakeholders interact and create value.

External knowledge is essential for developing successful new products (Feng, Cai, Zhang, \& Liu, 2016). Researchers and practitioners have considered customers' critical sources of superficial knowledge and looking for more involvement in the firm's operations and development. A better understanding of customer needs allows firms to access resources and information to achieve desirable performance. In addition, highly conscious customers will take legal action if they find that the food sold to Muslim customers is non-halal or that the product's halal status is uncertain (Samsi et al., 2011). Even though the findings of previous studies are not consistent in terms of the relationship between customer engagement and firm practices (Feng et al., 2016; Lau, 2011) most studies of halal logistics practices have resulted in customer involvement in market opportunity analysis (Aziz \& Chok, 2013; Fathi, Zailani, Iranmanesh, \& Kanapathy, 2016). Thus, a further study examining customers' engagement in implementing halal logistics practices should be considered. Therefore, it is hypothesized that:

H1: There is a positive relationship between customer engagement and halal logistics practices.

Effectiveness and efficiency in supply chain coordination require good relationships and integration between all processes. It is hard to compete with profit without having a good collaborative relationship and partnership with the suppliers (Huang, Yen, \& Liu, 2014). Performing halal products has forced the firms to deal with halal-certified suppliers to ensure the products will not mistakenly contaminate non-halal products and supply chain transfer. Hence, it is crucial to consider supplier engagement towards halal logistics practices since previous studies have also highlighted that responsiveness of the supply chain does not depend only on a single firm's performance but also on the impact from suppliers' performance (Chuah, Wong, Ramayah, \& Jantan, 2010). Therefore, it is hypothesized that:

H2: There is a positive relationship between suppliers' engagement and halal logistics practices.

Nowadays, Muslim consumers will choose halal-certified products and services. Non-Muslims also believe that halal-certified products offer high-quality products and services (Ab Talib et al., 2013). In this study, the critical aspect of the halal logistic practices implementation highlights the importance of competitors' analysis. Competitors are defined as firms offering similar products and services because they provide the exact customer needs (Sørensen, 2009). A firm with similar products may differ through production technology platforms. Therefore, it is hypothesized that:

H3: There is a positive relationship between analysis on competitors' and halal logistics practices.

On the other hand, governments are legitimate and usually powerful stakeholders who can exert influence and support through legislation, regulation, and policies (Sarkis et al., 2010). In 2010, Halal Development Center, Malaysia, as halal authorities, launched many halal programs for logistics service providers. The government also offered the investment tax allowance of $100 \%$ of qualifying capital expenditure incurred within five years for halal- 
certified logistics service providers. Furthermore, in 2010, Malaysia launched the Standards of Halal Logistics, which cover transportations, warehouses, and retail (Iskandar, Tan, Razali, \& Husny, 2012). Besides, government support may vary, including finance, technology, and law (Lin \& Ho, 2008). This study will empirically test if government support influences halal manufacturers to adopt halal logistics practices. Therefore, it is hypothesized that:

H4: There is a positive relationship between government support and halal logistics practices.

Next, previous research believed that NGO (non-governmental organization) pressure can influence a firm's perception because community trust is often with them (Deegan \& Islam, 2014). NGOs and media help the societies monitor the wrongdoings of the industry players and attend to consumers' complaints and queries. The media act as a medium for consumer interactions that can be extremely complicated because it affects its reputation. Therefore, firms must handle and acknowledge the complexity (Papagiannidis, Bourlarkis, \& See-To, 2019). In Malaysia, some NGOs that are well established in discussing halal industries include Persatuan Penguna Islam Malaysia (PPIM) and International Halal Industry Alliance (IHI Alliance). Therefore, it is hypothesized that:

H5: There is a positive relationship between NGOs, community media, and society engagement, and halal logistics practices.

Furthermore, managers should efficiently manage at the organizational and supply chain levels. Most firms begin with a competitive strategy and then decide their supply chain strategy. The supply chain strategy determines how the supply chain needs to perform concerning efficiency and responsiveness. Effective and efficient management of the supply chain has been recognized as a crucial factor in differentiating the products and services and gaining competitive advantages. A measurement instrument including delivery reliability, responsiveness, reliability, cost and assets management efficiency is a set of measuring items performed to expose a theoretical concept. This SCOR model indicates how efficiently a firm utilizes its resources to create customer value. It considers member firms' performance expectations on both the input and output sides of supply chain activities. The performance measurement guidelines and measures in SCOR across supply chain participants provide a valuable framework for developing a construct and corresponding instrument for supply chain performance measurement in the context of halal logistics practices.

According to Tieman and Ghazali (2014) halal control activities and assurance activities are fundamental in establishing robust halal logistics practices and increasing supply chain performance that strives for a lower vulnerability of halal contamination. Therefore, halal logistics practices can help a firm maintain its halal integrity and improve the performance efficiency in logistics and supply chains. This research argues that implementing halal logistics through management responsibilities, risk management analysis, risk management process, and operation improves supply chain performance.

H5: There is a positive relationship between halal logistics practices and supply chain performance.

Stakeholder theory can help to explain the antecedents and consequences of adopting halal logistics practices, as shown in the theoretical framework Figure 1. According to the theory, firms produce externalities that affect their stakeholders (Sarkis et al., 2010). Individuals or groups with the power to influence a firm's performance or activities are known as stakeholders. There are three types of stakeholder theory: descriptive, normative, and instrumental (Donaldson \& Preston, 1995). The descriptive perspective simply states that organizations have stakeholders. The role of organizations is to satisfy a diverse range of stakeholders and not just the shareholders. In the meantime, the normative perspective examines why firms should consider their stakeholders.

The instrumental perspective is that firms that hold their stakeholders' interests will outperform those that do not consider their stakeholders. This research has implemented an instrumental view since this study has examined the connection between stakeholder influences and halal logistics practices. Stakeholder theory suggests that firms implementing stakeholder management will generally succeed in profitability, stability, growth, and performance, assuming all other variables remain unchanged. As a result, besides balancing the benefits of shareholders, firms 
must also consider the interests of different stakeholders. They may be the ones who have a significant impact on implementing halal logistical procedures.

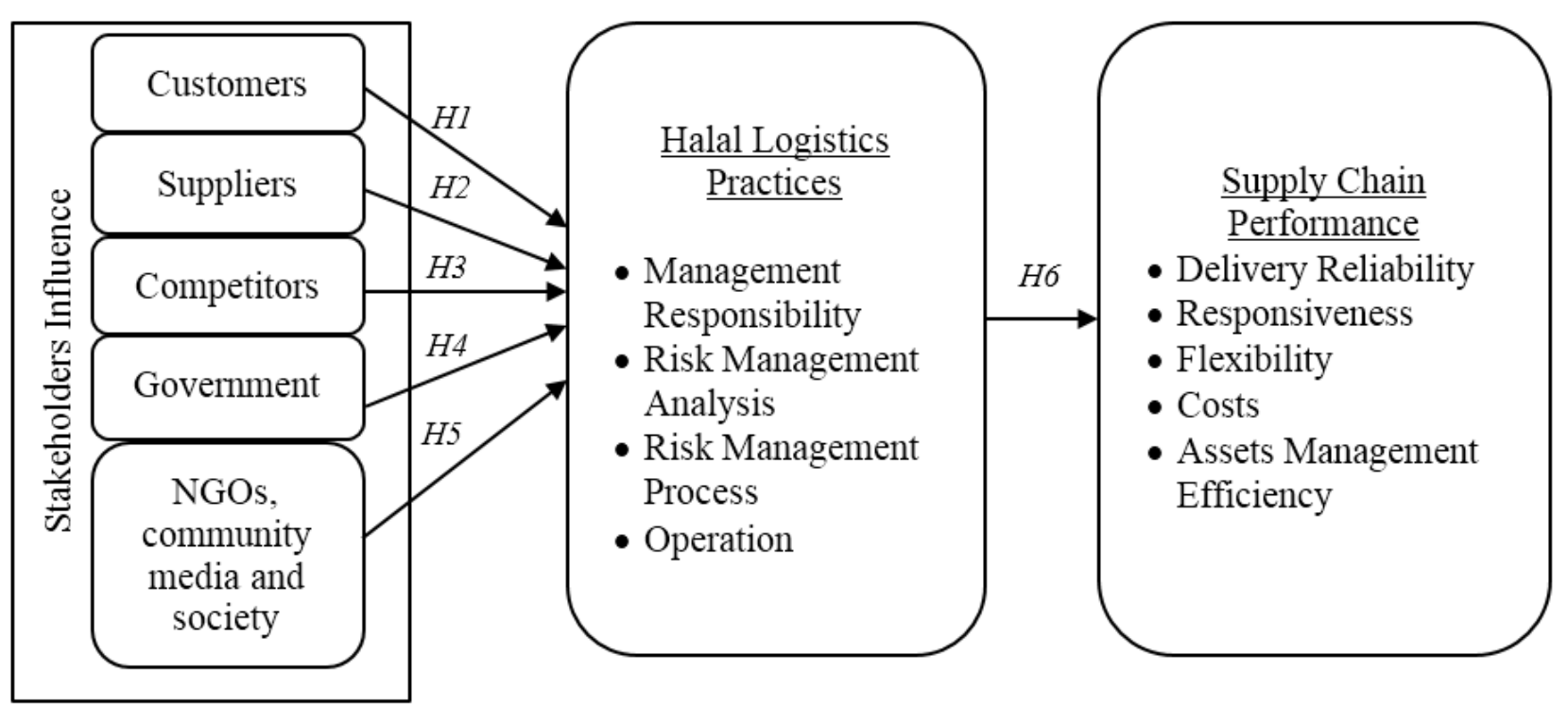

Figure-1. Theoretical framework.

\section{RESEARCH METHODOLOGY}

A questionnaire survey was disseminated to Malaysian manufacturers, including halal food, halal cosmetics, and halal pharmaceutical manufacturers, by email, phone conversation, and direct face-to-face connection. A total of 270 replies were collected at the end of the data collecting period and used for further analysis. The respondents of this study were the business owner or individuals at managerial levels responsible for the company's operations aspect. This study used a close-ended questionnaire as a research instrument. The instruments used to measure each of the constructs were multi-item scales, which were adopted and modified from previously established research to fit the context of this study.

The measurement for stakeholder influences comprised five seven-point Likert scale items ranging from $1=$ strongly disagree to $7=$ strongly agree. The customer variable's measurement was adopted from the engagement with customers by Feng et al. (2016) and suppliers' measurement was adopted from Chuah et al. (2010). Furthermore, the measurement of competitors was taken from Sørensen (2009) and the measurement of government support was taken from Lin and Ho (2008). Lastly, NGOs, community media, and society were adopted from the overall media influence (Deegan \& Islam, 2014).

Furthermore, based on the extensive literature review, four primary halal components were established: management responsibilities, risk management analysis, risk management process, and operations. The measurement of halal logistics practices is developed from the Department of Standards Malaysia's MS2400:2019 Halal Supply Chain Management System, and prior studies by Tieman and Ghazali (2014); Nor, Jaafar, and Ahmad (2016). The Halalan-Toyyiban Assurance Pipeline MS2400:2019 is an updated version of the previous version (MS2400:2010). A 7-point Likert scale is used to measure the halal logistics practices implementation in the organization ( $1=$ strongly disagree; $7=$ strongly agree).

Meanwhile, supply chain performance was measured using items adapted from Theeranuphattana and Tang (2007); Cirtita and Glaser-Segura (2012), and Anatan (2014). These variables include supply chain delivery reliability, responsiveness, flexibility, costs, and assets management efficiency. Respondents were required to rate their feedback towards the consequences or outcomes of business performance after implementing halal logistics practices based on a 7-point evaluative scale ranging from 1 (not at all important) to 7 (extremely important). 
The items in stakeholder influence, halal logistics practices and supply chain performance were examined the reliability and validity. The Cronbach's Alpha coefficient and composite reliability were calculated for all scales in this study to assess the reliability of the multi-item scale for each variable. The reliability measures have been exceeded the acceptable threshold standard of 0.7 (Hair, Anderson, Tatham, \& Black, 1998). It concluded that the measurement has internal consistency. The final items retained for hypothesis testing are reported in Table 1.

Table-1. Reliability Analysis on Cronbach Alpha Coefficient.

\begin{tabular}{l|l|c|c}
\hline No & Variables & Number of Items & Cronbach Alpha \\
\hline a. & Customer & 6 & 0.877 \\
\hline b. & Supplier & 5 & 0.830 \\
\hline c. & Competitor & 7 & 0.864 \\
\hline d. & Government & 5 & 0.848 \\
\hline e. & NGOs, community media, and society & 4 & 0.906 \\
\hline f. & Halal logistics practices & 56 & 0.973 \\
\hline g. & Supply Chain Performance & 28 & 0.963 \\
\hline
\end{tabular}

\section{DATA ANALYSIS AND RESULTS}

Data were analyzed using IBM SPSS statistics (SPSS) 26 for descriptive analysis and regression analysis. Results indicate most of the companies that participated were established between 11 to 15 years (30.7\%), companies operating between 6 to 10 years (27.4\%), companies operating more than 15 years (23.7\%), and companies operating between 1 to 5 years (18.1\%). Meanwhile, $100 \%$ of respondents use in-house warehouse operation, $47.0 \%$ use in-house transportation, and 53\% use third-party transportation. Finally, $87 \%$ of the respondents possess halal food certification (MS1500:2009), 10\% possess halal pharmaceutical certification (MS2424:2012) and 7\% possess halal cosmetics certification (MS2634:2019). Some respondents have more than one credential because they manufacture many products in one of the firms.

Results revealed that the average number of halal logistics practices is relatively high, with a mean of 5.310. This indicates that although halal-certified manufacturers in Malaysia have adopted halal logistics practices, despite not being halal-certified with halal supply chain Malaysia. Operations practices have a much higher mean of 5.534 followed by management responsibility aspect, with 5.377. Meanwhile, the risk management process has 5.362 and the risk management analysis with 5.274. The result indicates that the firm's practices operational aspects of halal logistics, focusing on the warehouse, handling, cleaning, and contamination factors. Regression analysis was conducted to investigate antecedents of logistics practices by analyzing the relationship between stakeholders' influences, halal logistics practices, and supply chain performance.

The regression result in Table 2 shows that customers, suppliers, government, NGOs, community media, and society have significantly affected the relationship. On the other hand, suppliers indicate an insignificant relationship with halal logistics practices. Furthermore, Table 3 explains that halal logistics practices significantly affected the relationship with supply chain performance.

Table-2. Result of Regression Analysis on Stakeholder Influence.

\begin{tabular}{l|c|c|c|c|c}
\hline \multirow{2}{*}{ Model } & \multicolumn{2}{c|}{$\begin{array}{c}\text { Unstandardized } \\
\text { Coefficients }\end{array}$} & $\begin{array}{c}\text { Standardized } \\
\text { Coefficients }\end{array}$ & \multirow{2}{*}{ t } & \multirow{2}{*}{ Sig. } \\
\cline { 1 - 3 } & $\mathbf{B}$ & Std. Error & Beta & & \\
\hline Intercept & 0.901 & 0.111 & & 8.079 & 0.000 \\
\hline Customers & 0.138 & 0.036 & 0.158 & 3.849 & 0.000 \\
\hline Suppliers & -0.034 & 0.033 & -0.040 & -1.022 & 0.308 \\
\hline Competitor & 0.359 & 0.032 & 0.438 & 11.307 & 0.000 \\
\hline Government & 0.263 & 0.027 & 0.345 & 9.859 & 0.000 \\
\hline NGOs, community media and society & 0.109 & 0.020 & 0.171 & 5.381 & 0.000 \\
\hline Note: Dependent variable: Halal logistics practices.
\end{tabular}


Table-3. Result of regression analysis on halal logistics practices.

\begin{tabular}{l|c|c|c|c|c}
\hline \multirow{2}{*}{ Model } & \multicolumn{2}{|c|}{$\begin{array}{c}\text { Unstandardized } \\
\text { Coefficients }\end{array}$} & $\begin{array}{c}\text { Standardized } \\
\text { Coefficients }\end{array}$ & \multirow{2}{*}{ Sig. } \\
\cline { 2 - 6 } & $\mathbf{B}$ & Std. Error & Beta & 3.977 & 0.000 \\
\hline Intercept & 0.984 & 0.248 & & 0.000 \\
\hline Halal logistics practices & 0.862 & 0.046 & 0.751 & 18.610 \\
\hline
\end{tabular}

Note: Dependent variable: Supply Chain Performance.

Meanwhile, this study has two endogenous constructs that could demonstrate the $\mathrm{R}^{2}$ value, as reflected in Table 4. Halal logistics practices value of $\mathrm{R}^{2}=0.871$ indicated stakeholder influence, including customers, suppliers, competitors, government and NGOs, community media, and society, accounted for $87.1 \%$ of the variance in halal logistics practices. Furthermore, the $\mathrm{R}^{2}$ value of 0.564 for SCP suggested that halal logistics practices accounted for $56.4 \%$ of SCP variance. Both $\mathrm{R}^{2}$ scores for halal logistics practices and SCP were substantial and moderate in explanatory power, as the value of $\mathrm{R}^{2}$ was more significant than 0.33 (Chin, 1998).

Table-4. Coefficient of Determination $\left(\mathrm{R}^{2}\right)$

\begin{tabular}{l|c|c}
\hline Construct & $\mathbf{R}^{2}$ & Explanatory Power \\
\hline Halal Logistics Practices & 0.871 & Substantial \\
\hline Supply Chain Performance & 0.564 & Moderate \\
\hline \multicolumn{2}{l}{ Note: R score interpretation (0.6: substantial, 0.33: moderate, 0.19: weak) (Chin, 1998). }
\end{tabular}

\section{DISCUSSION ON THE RESULT AND FINDINGS}

It has been reported that only limited numbers of companies invest in halal logistics operations, and these facilities and infrastructures have been underutilized (Ab Talib, Hamid, \& Zulfakar, 2015). The industry players claimed that the investment made for halal logistics practices is not cost-effective (Ab Talib et al., 2013) and they failed to reap the full benefits. Meanwhile, other previous research has claimed that adopting halal logistics practices is profitable because it will lead to financial performance (Byrd \& Davidson, 2003). Within management responsibilities, risk management analysis, risk management process, and operational context of halal logistics practices, the current study has found halal manufacturers in Malaysia are embracing halal logistics practices. These results provided significant empirical evidence on their readiness to adopt MS2400:2019 Halal Supply Chain Management System.

Since the respondent in this study is halal certified manufacturers (MS1500:2009, MS2424:2012, MS2634:2019), it can be concluded that the Quality Management System such as ISO 9001:2015 could have a positive impact on the readiness of halal manufacturers on implementing halal logistics practices. Based on the measurement used, the result signifies that the procedure and standards established in the firm in compliance with halal standards have made these companies accustomed to all the halal logistics requirements. Halal manufacturers require strict practices for physical segregation and additional criteria according to the religion of Muslim markets.

Furthermore, the result has shown that competitors, government, NGOs, community media, and society, and customers have a significant relationship with implementing halal logistics practices. The finding of this study shows that competitors were the most important influence on the performance of halal logistics practices. This result contradicts what has been found in the halal food and halal cosmetics industry, in which the most prominent influence is from the consumers (Haleem \& Khan, 2017; Hima et al., 2016). It is indicated that consumers are more concerned about the halal status of the products, while so far less awareness and concern with the halal logistics aspect. However, firms see that halal logistics standards can be used as a competitive advantage, especially when competitors adopt them. Barney (2001) has highlighted that competitive advantages are from a value-adding strategy and separately implemented by competitors. When the operations competency is unique in the marketplace, it will give a differential advantage to the firms. 
The government has played an essential role in the development of halal standards and business processes in Malaysia. Implementation of halal standards such as halal supply chain certification requires financial, policy, and incentives support. The government's huge initiatives, such as funding, international footprint, and halal occupational framework, have been prepared for halal industry players. The total commitment given through the government has also helped industry players contribute in implementing halal logistics practices to ensure a global trust in Malaysia accreditation and compatibility with halal emerging markets. Therefore, this explained the significant relationships between government support and halal logistics practices.

Meanwhile, the relevance of media attention in this study is enormous when visibility has strengthened as the most crucial factor contributing to the success or failure of the business community. Thus, many Muslim NGOs, community media, and society are engaged in the halal industry to recognize their awareness of the need to protect Muslim consumers and foster sensitivity among Muslims of the food status they are about to consume. They highlighted problems, queries, and complaints from customers and assisted the government in monitoring and enforcing policies (Samsi et al., 2011). As a result, exposure to NGOs, community media, and society has influenced halal industry players to incorporate halal logistics practices in their business operations.

However, the supplier is not significant towards implementing halal logistics practices. Even though previous research has highlighted that suppliers' response can influence the decision making by the firm (Din \& Daud, 2014) there is some possibility that in halal practices, the manufacturer pushes the supplier to offer halal goods, not the other way around. For example, the raw materials must also meet the halal requirements for a halal producer. Furthermore, previously limited research regarding the relationship between suppliers and halal logistics conducted by Haleem and Khan (2017) and Samsi et al. (2011) was not empirically tested. Thus, results cannot be generalized. It is an exciting finding compared to halal certification for products in which halal-certified suppliers in pertinent.

Significant results in analyzing halal logistics practices toward supply chain performance have proven that supply chain performance is a different way of measuring the strategic performance of the firms. Best practices of management responsibilities, risk management analysis, risk management process, and operation in halal logistics have protected the halal integrity throughout the supply chain until the end consumers. Practicing halal logistics will indirectly improve supply chain performance since logistics is a key for corporate strategy (Sandberg \& Abrahamsson, 2010). For example, consumers' responsiveness towards demand may increase the delivery responsiveness and consistency of lead time. Furthermore, the firms are flexible in delivery systems to help consumers place their orders. Moreover, managing total operations costs and controlling assets management is vital in maximizing efficient and effective operations that directly lead to increased supply chain performance.

\section{CONCLUSIONS}

Logistics plays a vital role in today's business because it can provide a competitive advantage to the companies, especially in terms of cost and time which are the ingredients for competitiveness. For a halal product manufacturer, maintaining the product's halal status all along the supply chain is pertinent for halal integrity and sanctity. While most companies in Malaysia are halal certified, their adoption of the MS2400:2019 Halal Supply Chain Management System is relatively low. Therefore, it is unknown about their readiness and practices towards halal logistics, which is the main element in supply chain management. This study has provided significant empirical evidence that halalcertified manufacturers in Malaysia indicate some level of readiness towards halal logistics practices in their operations.

Five main stakeholders were identified. Results revealed that competitors greatly influence firms implementing halal logistics practices followed by government, NGOs, community media and society, and customers. There is no significant relationship between the influence of suppliers towards halal logistics practices. By closely looking at the different stakeholders, a greater understanding of the relationship can be achieved to meet stakeholder expectations 
of the firms. Managing the relationships with each stakeholder can help the firm guide the firm's actions and initiatives to create, build, and strengthen the firm's bonds with each stakeholder.

This study has also investigated the antecedence of halal logistics practices by explicitly looking at stakeholders' roles. This study confirmed that stakeholders certainly could pressure firms to implement new techniques within the context of the halal industry. It implies that firms should understand that different stakeholders have different responsibilities in channelizing halal goods to increase consumer demand. Firms need to be aware and understand the interest of every stakeholder in the industry, and it is sometimes worth taking their opinion and involving them in some decision-making process and activity. In the previous research of halal product certification, it was found that customers act as the primary pressure for firms to adopt halal certification. Interestingly, this study found that competitors who give strong influence in adopting halal logistics practices. It is an essential finding of this study.

Meanwhile, procedures and standards developed in the firm according to halal standards lead to an efficient process. The present study has provided new evidence in a theoretical perspective that stringent operation required in halal logistics practices can improve the supply chain performance of firms within the halal context. In addition, continuous communication from time to time in industry players can improve the quality of halal products.

Another significant contribution of this study is developing a constructive measure of halal logistics practices. Most previous studies on halal logistics have used a qualitative research method, and there was no instrument available to measure a holistic view of halal logistics practices. While previous research provides a strong base for the theory, no scale was developed to allow a quantitative study approach on halal logistics. This research has established a methodology for assessing halal logistics practices. Thus, it will enable a quantitative research method and generalization of the findings.

To conclude, this research has explored the new upcoming area of halal logistics. The outcome of this study has provided empirical evidence that initiates interest to the academicians for future research and actions plans for various stakeholders and policy planners.

Funding: This study received no specific financial support.

Competing Interests: The authors declare that they have no competing interests

Acknowledgement: All authors contributed equally to the conception and design of the study.

\section{REFERENCES}

Ab Talib, M. S., \& Hamid, A. B. A. (2004). Halal logistics in Malaysia: A SWOT analysis. Journal of Islamic Marketing, 5(3), 322343.

Ab Talib, M. S., Hamid, A. B. A., \& Zulfakar, M. H. (2015). Halal supply chain critical success factors: A literature review. Journal of Islamic Marketing, 6(1), 44-71. Available at: https://doi.org/10.1108/jima-07-2013-0049.

Ab Talib, M. S., Rubin, L., \& Zhengyi, V. K. (2013). Qualitative research on critical issues in halal logistics. Journal of Emerging Economies and Islamic Research, 1(2), 131-150. Available at: https://doi.org/10.24191/jeeir.v1i2.9125.

Abd Rahman, A., Abd Mubin, N., Yusof, R. N. R., \& Kamarulzaman, N. H. (2021). Building supply chain performance through halal logistics, organisational capabilities and knowledge management. International Journal of Logistics Research and Applications, 1-23. Available at: https://doi.org/10.1080/13675567.2021.1969347.

Abd Rahman, A., \& Abdul, M. (2017). Establishment of traceability practices through halal assurance system (HAS) implementation. International Journal of Academic Research in Business and Social Sciences, 7(6), 130-139. Available at: https://doi.org/10.6007/ijarbss/v7-i6/2951.

Anatan, L. (2014). Factors influencing supply chain competitive advantage and performance. International Journal of Business \& Information, 9(3), 311-334 
Aziz, Y. A., \& Chok, N. V. (2013). The role of Halal awareness, Halal certification, and marketing components in determining Halal purchase intention among non-Muslims in Malaysia: A structural equation modeling approach. Journal of International Food \& Agribusiness Marketing, 25(1), 1-23. Available at: https://doi.org/10.1080/08974438.2013.723997.

Backer, L. (2007). Engaging stakeholders in corporate environmental governance. Business and Society Revierw, 112(1), 29-54. Available at: https://doi.org/10.1111/j.1467-8594.2007.00285.x.

Balzarova, M. A., \& Castka, P. (2012). Stakeholders' influence and contribution to social standards development: The case of multiple stakeholder approach to ISO 26000 development. Journal of Business Ethics, 111(2), 265-279. Available at: https://doi.org/10.1007/s10551-012-1206-9.

Barney, J. B. (2001). Resource-based theories of competitive advantage: A ten-year retrospective on the resource-based view. Journal of Management, 27(6), 643-650. Available at: https://doi.org/10.1177/014920630102700602.

Bernon, M., Bastl, M., Zhang, W., \& Johnson, M. (2018). Product recalls: The effects of industry, recall strategy and hazard, on shareholder wealth. International Journal of Business Science \& Applied Management, 13(1), 1-13.

Bierbooms, J., Van Oers, H., Rijkers, J., \& Bongers, I. (2016). Development of a comprehensive model for stakeholder management in mental healthcare. Journal of Health Organization and Management, 30(4), 630-647. Available at: https://doi.org/10.1108/jhom-01-2016-0004.

Byrd, T. A., \& Davidson, N. W. (2003). Examining possible antecedents of IT impact on the supply chain and its effect on firm performance. Information \& Management, 41(2), 243-255. Available at: https://doi.org/10.1016/s0378-7206(03)00051$\mathrm{x}$.

Chin, W. W. (1998). Commentary: Issues and opinion on structural equation modelling. MIS Quarterly, $22(1), 1$.

Chuah, P., Wong, Q. P., Ramayah, T., \& Jantan, M. (2010). Organizational context, supplier management practices and supplier performance. Journal of Enterprise Information Management, 23(6), 724-758. Available at: https://doi.org/10.1108/17410391011088619.

Cirtita, H., \& Glaser-Segura, D. A. (2012). Measuring downstream supply chain performance. Journal of Manufacturing Technology Management, 23(3), 299-314.

Deegan, C., \& Islam, M. A. (2014). An exploration of NGO and media efforts to influence workplace practices and associated accountability within global supply chains. The British Accounting Review, 46(4), 397-415. Available at: https://doi.org/10.1016/j.bar.2014.10.002.

Din, R. C., \& Daud, S. (2014). Critical success factors of MS1500: 2009 implementation. Procedia-Social and Behavioral Sciences, 121, 96-103. Available at: https://doi.org/10.1016/j.sbspro.2014.01.1111.

DinarStandard. (2020). 2019 November 14 (pp. 2-5). Report State of the Global Islamic Economy 2019/20. SalaamGateway.com.

Donaldson, T., \& Preston, L. E. (1995). The stakeholder theory of the corporation: Concepts, evidence, and implications. Academy of Management Review, 2O(1), 65-91.

Fathi, E., Zailani, S., Iranmanesh, M., \& Kanapathy, K. (2016). Drivers of consumers' willingness to pay for halal logistics. British Food Journal, $118(2)$, 464-479. Available at: https://doi.org/10.1108/bfj-06-2015-0212.

Feng, T., Cai, D., Zhang, Z., \& Liu, B. (2016). Customer involvement and new product performance: The jointly moderating effects of technological and market newness. Industrial Management \& Data Systems, 116(8), 1700-1718. Available at: https://doi.org/10.1108/imds-11-2015-0457.

Freeman, R. E., \& Phillips, R. A. (2002). Stakeholder theory: A libertarian defense. Business Ethics Quarterly, 12(3), $331-349$. Available at: https://doi.org/10.2307/3858020.

Hair, J. F., Anderson, R. E., Tatham, R. L., \& Black, W. C. (1998). Multivariate data analysis (5th ed.). Upper Saddle River, NJ: Prentice Hall.

Haleem, A., \& Khan, M. I. (2017). Towards successful adoption of halal logistics and its implications for the stakeholders. British Food Journal, $119(7)$, 1592-1605. Available at: https://doi.org/10.1108/bfj-12-2016-0637.

Halid, S. (2012). The recovery of the halal industry is an important agenda of the VAT-Prime Minister. Daily news. Retrieved at 16 Sept 2021. 
Hima, N., Rahim, M., Mohd, S., \& Zainuddin, A. (2016). Halal supply chain stakeholders' engagement programme - initial exploratory analysis towards retail study in Malaysia. Paper presented at the Qualitative Research Conference. Malaysia.

Huang, M.-C., Yen, G.-F., \& Liu, T.-C. (2014). Reexamining supply chain integration and the supplier's performance relationships under uncertainty. Supply Chain Management: An International Journal, 19(1), 64-78. Available at: https://doi.org/10.1108/scm-04-2013-0114.

Iskandar, M., Tan, I., Razali, R. N., \& Husny, Z. J. (2012). The adoption of halal transportations technologies for halal logistics service providers in Malaysia. International Journal of Mechanical. Industrial Sciene and Engineering, 6(3), 10-17.

Jaafar, H. S., Faisol, N., Abdul Rahman, F., \& Muhammad. (2017). A halal logistics vs halal supply chain: A preliminary insight. Contemporary issues and development in the global halal industry (pp. 579-588). Singapore: Springer.

Lau, A. K. (2011). Supplier and customer involvement on new product performance: Contextual factors and an empirical test from manufacturer perspective. Industrial Management \& Data Systems, 111(6), 910-942. Available at: https://doi.org/10.1108/02635571111144973.

Lin, C.-Y., \& Ho, Y.-H. (2008). An empirical study on logistics service providers' intention to adopt green innovations. Journal of Technology Management \& Innovation, 3(1), 17-26.

Macchion, L., Danese, P., \& Vinelli, A. (2015). Redefining supply network strategies to face changing environments. A study from the fashion and luxury industry. Operations Management Research, 8(1-2), 15-31. Available at: https://doi.org/10.1007/s12063-014-0097-6.

Meixell, M. J., \& Luoma, P. (2015). Stakeholder pressure in sustainable supply chain management: A systematic review. The Impact of Relationship History on Negotiation Strategy Expectations, 45(1/2), 69-89. Available at: https://doi.org/10.1108/ijpdlm-05-2013-0155.

Ngah, A. H., Zainuddin, Y., \& Thurasamy, R. (2015). Barriers and enablers in adopting of Halal warehousing. Journal of Islamic Marketing, 6(3), 354-376. Available at: https://doi.org/10.1108/jima-03-2014-0027.

Nor, H. M., Jaafar, H. S., \& Ahmad, N. (2016). Establishing a logistics cost concept in halal logistics : From perspective of logistics service providers point of view. Journal of Applied Environmental and Biological Sciences, 6(11S), 59-63.

Papagiannidis, S., Bourlarkis, M., \& See-To, E. (2019). Social media in supply chain and logistics: Contemporary trends and themes. International Journal of Business Science and Applied Management, 14(1), 17-34.

Russo, A., \& Perrini, F. (2010). Investigating stakeholder theory and social capital: CSR in large firms and SMEs. Journal of Business Ethics, 91(2), 207-221. Available at: https://doi.org/10.1007/s 10551-009-0079-z.

Samsi, S. Z. M., Tasnim, R., \& Ibrahim, O. (2011). Stakeholders' role for an efficient traceability system in halal industry supply chain. Paper presented at the Annual International Conference on Enterprise Resource Planning and Supply Chain Management.

Sandberg, E., \& Abrahamsson, M. (2010). The role of top management in supply chain management practices. International Journal of Retail \& Distribution Management, 38(1), 57-69.

Sarkis, J., Gonzalez-Torre, P., \& Adenso-Diaz, B. (2010). Stakeholder pressure and the adoption of environmental practices: The mediating effect of training. Journal of Operations Management, 28(2), 163-176. Available at: https://doi.org/10.1016/j.jom.2009.10.001.

Sharma, S., \& Henriques, I. (2005). Stakeholder influences on sustainability practices in the Canadian forest products industry. Strategic Management Journal, 26(2), 159-180. Available at: https://doi.org/10.1002/smj.439.

Sørensen, H. E. (2009). Why competitors matter for market orientation. European Journal of Marketing, 43(5-6), 735-761. Available at: https://doi.org/10.1108/03090560910947025.

Theeranuphattana, A., \& Tang, J. C. S. (2007). A conceptual model of performance measurement for supply chains. Journal of Manufacturing Technology Management, 19(1), 125-148.

Tieman, M., \& Ghazali, M. C. (2014). Halal control activities and assurance activities in halal food logistics. Procedia-Social and Behavioral Sciences, 121, 44-57. Available at: https://doi.org/10.1016/j.sbspro.2014.01.1107. 
Yunos, R. M., Mahmood, C. F. C., \& Abd Mansor, N. H. (2014). Understanding mechanisms to promote halal industry-the stakeholders' views. Procedia-Social and Behavioral Sciences, 130, 160-166. Available at: https://doi.org/10.1016/j.sbspro.2014.04.020.

Zidane, Y. J., Johansen, A., Ekambaram, A., \& Hald, L. C. (2015). When stakeholders shape successes or bring failures-a case study of an Algerian megaproject. Procedia Computer Science, 64, 844-851. Available at: https://doi.org/10.1016/j.procs.2015.08.637.

\section{APPENDIX}

\section{Questionnaire items used in the study:}

\section{Customers}

1. Our organization has consulted significant customers at the beginning of the implementation of halal logistics practices.

2. Our organization partnered with major customers to develop halal products.

3. The major customer was an integral part of implementing halal logistics practices in halal product development.

4. The major customer was frequently consulted about halal practices.

5. Our organization has continuous improvement programs that include our primary customers.

\section{Suppliers}

1. The suppliers inform the company of major changes in their organization.

2. The suppliers give a hint of more potential business for our organization.

3. The supplier is invited to our company to improve awareness about our organization.

4. Our organization takes advantage of the technical support and test capabilities provided by the suppliers.

\section{Competitors}

1. Our organization tracks the performance of key competitors.

2. Our organization identifies the areas where the key competitors have succeeded or failed.

3. All of our managers understand how every business function can contribute to the information on competitive activities.

4. Our organization targets customers where we have an opportunity for competitive advantage.

5. Our organization rapidly responds to competitive actions that threaten us.

6. Our organization looks for market opportunities that do not threaten competitors.

\section{Government}

1. The government provides financial support for developing halal logistics practices.

2. The government encourages companies on preparing a halal logistics environment.

3. Government helps training the workforce with halal logistics knowledge and skills.

4. Government sets the regulations for the halal logistics industry.

\section{NGOs, Community Media, and Society}

1. NGOs, community media, and society influence both the social performance of organizations products.

2. The media does influence corporate social performance.

3. NGOs use the media to influence both the workplace practices utilized by organizations supplying products and act to disclosure practices.

4. Overall, I believe that NGOs, community media, and societies influence the implementation of halal logistics. 


\section{Halal Logistics Practices}

Management Responsibilities

1. Our current logistics policy is relevant and comply with the requirement of Malaysia Standard HalalanToyyiban Assurance Pipeline MS2400:2010.

2. We appoint a halal leader in the organization.

3. A halal leader has the appropriate qualification, education, knowledge, and experience on halal and non-halal processes.

4. We have appointed a halal committee in the organization.

5. Halal committee members have the appropriate knowledge and training on halal and non-halal processes.

6. We have appointed Shariah, advisor of the halal management system in the organization.

7. A halal leader will refer to a recognized Shariah advisor who acts as a reference point in any matter from implementing the halal management system.

8. Our current logistics policy is relevant and complies with the requirement of Malaysian Standard HalalanToyyiban Assurance Pipeline MS2400:2010.

Risk Management Analysis

9. We have a list of potential contaminants or precursors.

10. We have rational inclusion or exclusion as a potential contaminant.

11. We have evaluated the likelihood and severity of potential precursors.

12. We provide the control measures for Halal Control Point

13. Warehouse operation area has faced the most potential contaminant.

14. During the movement of goods (transportation) process has faced the most potential contaminant.

15. The human handling process has faced the most potential contaminant.

\section{Risk Management Process}

16. Our organization has a complete flow and diagrams of transportation processes covered by the HalalanToyyiban Risk Management.

17. All transportation facilities have a dedicated depot layout that permits adequate maintenance and cleaning.

18. The areas of cross-contamination of incidental contact with in-process and finished products have been segregated for inbound materials, raw materials and processing aids (such as chemicals, additives, lubricants, packaging, pallets, containers, etc.).

19. The mode of transportation operated under legal and halal requirements.

20. The third-party logistics transporter has complied with all existing legal and operation control.

21. The specific environmental transport condition has specifically defined and recorded including temperature, humidity, air pressure, controlled environment, drop and shock, compression loading, vibration and orientation, and segregation and separation of goods.

22. The information and documentation below have been prepared in all packed goods/ products while transferring the goods including loading information, sequence of loading, window delivery time, and product identification

23. The organization has documented guidelines for any loss and damage to the consignment throughout the transportation process.

24. Our organization has a complete flow and diagrams of warehousing processes covered by the HalalanToyyiban Risk Management.

25. Plant layout also includes inbound materials, intermediate materials, finished products, goods, and personnel use. 
26. The areas of cross-contamination of incidental contact with in-process and finished products have been segregated at inbound materials, raw materials, and processing aids (such as chemicals, additives, lubricants, packaging, pallets, containers, etc.).

27. The area of warehouse facilities is dedicated explicitly to planting layout including quarantine, receiving, sorting, sanitary facilities, pest control, and waste disposal.

28. The specific environment of warehouse condition has been specifically defined and recorded such as temperature, humidity, air pressure, controlled environment, drop and shock, compression loading, vibration and orientation and segregation and separation of goods.

29. Our organization has documented a procedure set if there are any loss and damage of consignment throughout the transportation process.

30. Our organization has monitored the performance of outsourced services providers (if any) to ensure compliance with halal requirements.

\section{Operations}

31. Our warehouse is being located far away from environmentally polluted areas and industrial activities with a severe threat.

32. Our warehouse is being located far away from areas subject to flooding.

33. Our warehouse is being located far away from pest infestation areas.

34. Our warehouse is being located far away from areas where wastes, either solid or liquid, cannot be removed effectively.

35. Our organization has documented guidelines for any loss and damage to the consignment throughout the transportation process.

36. Our organization has monitored the performance of outsourced services providers (if any) to ensure compliance with halal requirements.

37. The design and construction of the equipment have followed the specific requirement including materials with no toxic effect in the intended use, adequately cleaned, disinfected, and maintained, and durable, movable, and capable of being disassembled.

38. Containers with waste, by-products, and inedible or dangerous substances have specifically identifiable and suitably constructed.

39. There is an adequate supply of potable water with appropriate storage area, distribution, and temperature control.

40. Non-potable water (e.g., fire control) has a separate system and is not connected with the current water system.

41. The floor and drainage systems are suitable for the proper flow of water and waste.

42. Our organization has adequate facilities for cleaning the warehouse and its equipment.

43. We did separation on storage of consignment, non-consignment materials (e.g., cleaning materials, lubricants, fuels), and packaging materials (e.g., carton, pallets) according to the halal requirements.

44. Our organization has provided hygiene facilities to ensure employees' hygiene can be maintained and avoid contaminating goods.

45. Our organization has ensured that personnel who directly or indirectly comes in contact with the goods being handled under a certain level of cleanliness such as health status, medical examination, illness and injury, personnel cleanliness (e.g., cut and wounds, waterproof dressing, and proper handwashing technique), personnel behaviour (e.g., not smoking, spitting, chewing, or eating/drinking) and visitors to handling process areas also adhere to personnel hygiene provision.

46. Our organization has established a procedure of suitable cleaning methods.

47. Our organization has established a procedure for suitable cleaning material. 
48. The cleaning activities were continually and effectively monitored and recorded.

49. Our organization has ensured that Shariah ritual cleansing is performed when and where contamination by severe najs occurs.

50. When doubtful and contaminations arise, our management has established, implemented, and maintained procedures to manage potential emergencies resulting in contamination, including incidents relevant to the organisation's role.

51. When doubtful and contaminations arise, we have a documented procedure that records and is maintained to handle, control, and dispose of contaminated.

52. When doubtful and contaminations arise, all the contaminated or affected goods will be isolated and referred to the halal leader for decision.

53. When doubtful and contaminations arise, the goods or cargo handled under conditions in which control measures are not implemented are evaluated concerning the causes of contamination and the impact of contamination in terms of the halal perspective

54. When doubtful and contaminations arise, specific personnel will be dedicated to facilitated isolation, notification, and complete withdrawal.

55. When doubtful and contaminations arise, the appropriate communication processes have been established within the organization and to the external interested parties.

56. Overall, I believe halal logistics practices influence supply chain performance.

\section{Supply Chain Performance}

\section{Supply Chain Delivery Reliability}

1. The ability to meet promised delivery date defined as on-time and in-full shipments.

2. The accuracy in filling order.

3. Order cycle consistency such that there is a minimal variance in promised versus actual delivery.

4. Fill rate on baseline/in-stock items (percentage of the order included in initial shipment).

5. Completeness of order (percentage of line items eventually shipped complete).

\section{Supply Chain Responsiveness}

6. Length of promised order cycle times (from order submission to delivery).

7. Length of time to answer distribution partners/customers' queries.

8. Length of time to process a received order.

9. Length of time to produce and ship a received order.

\section{Supply Chain Flexibility}

10. The ability to identify and supply high volumes in a "quick ship" mode.

11. The ability to automatically back order baseline/ in-stock items under "quick ship" mode.

12. The ability to meet specific customer service needs.

13. The ability to plan, source, make and deliver unplanned orders with minimal cost penalties.

\section{Supply Chain Costs}

14. Cost for order management (such as purchase orders, expediting, etc.).

15. Cost of goods (such as direct cost of material and direct labour).

16. Cost of sales, contract administration, engineering, and lab support of products.

17. Cost of carrying inventory (such as warehouse and retail inventory).

18. Cost of transportation. 
19. Cost of warranty/return processing.

20. Total supply chain management cost.

Supply Chain Assets Management Efficiency

21. Cash-to-cash cycle time

22. Inventory days of supply

23. Asset turns

24. Gross margin

25. Operating income

26. Return on assets

27. Earnings per share

28. Overall, our organization should implement a good supply chain performance 